\title{
A Survey on Data Mining Techniques in the Medicative Field
}

\author{
Chinky Gera \\ M.Tech(CSE) Student \\ Department Of Computer Science \& Engineering \\ RIMT Institute of Engineering and Technology
}

\author{
Kirti Joshi \\ Assistant Professor \\ Department Of Computer Science \& Engineering \\ RIMT Institute of Engineering and Technology
}

\begin{abstract}
Data mining is the process of releasing concealed information from a large set of database and it can help researchers gain both narrative and deep insights of exceptional understanding of large biomedical datasets. Data mining can exhibit new biomedical and healthcare knowledge for clinical decision making. Medical assessment is very important but complicated problem that should be performed efficiently and accurately. The goal of this paper is to discuss the research contributions of data mining to solve the complex problem of Medical diagnosis prediction. This paper also reviews the various techniques along with their pros and cons. Among various data mining techniques, evaluation of classification is widely adopted for supporting medical diagnostic decisions.
\end{abstract}

\section{General Terms}

Data Mining, Classification, Medical.

\section{Keywords}

Classification, Decision Tree, K means Clustering, Naïve Bayes, WEKA.

\section{INTRODUCTION}

Data mining is one of the provoking and significant area of research. Data mining is implicit and non-trivial task of identifying the viable, novel, inherently efficient and perspicuous patterns of data. Figure 1 represents the data mining as part of KDD process [15]. The hidden relationships and trends are not precisely distinct from reviewing the data. Data mining is a multi-level process involves extracting the data by retrieving and assembling them, data mining algorithms, evaluate the results and capture them. [10] Data Mining is also revealed as necessary process where bright methods are used to extract the data patterns by passing through miscellaneous data mining processes.

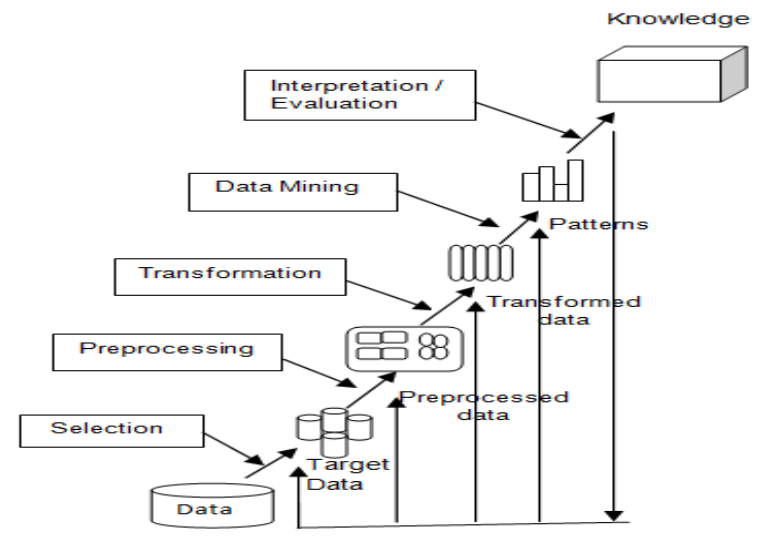

Fig 1: Data Mining Processes [15]
The cause of data mining effort is usually either to design a descriptive model or a predictive model. Descriptive mining functions specify the common properties of the data in the database. Predictive mining functions perform the reasoning on the present data in order to form predictions. From a general view, there is a robust consent between both researchers and executives about the standard that all data mining techniques must meet. Classification and Prediction are two designs of data analysis that can be used to extract models illustrating the essential data classification or to predict the future data mode. Such analysis can assist to provide with a better knowledge of the data tremendously. [4]

\section{DATA MINING TECHNIQUES IN MEDICAL SCIENTIFIC DISCIPLINE}

In medical data mining, some techniques like Multilayer Perceptron, J48 Decision Tree, KNN, K-Clustering, Random Forest has been widely used by authors in their research work. Table 1 enlists the pros and cons data mining techniques. We have briefly discussed these techniques:

\subsection{Neural Network}

Classification is one of the most dynamic research and significant area of neural networks. This paper summarizes vital growth in neural network classification analysis. In medical field, the neural network manipulates the predictive decision making by the described set of rules. Neural network provide powerful mechanism to help the physicians to review, model and make sense of complex clinical data across medical applications. [6] [9]

\subsection{Decision Tree}

There are some standard tree algorithms are implemented: ID3 and C4.5 (called version J48). J48 is mostly used as compared to ID3 as J48 yields better results in any context. In the WEKA data mining tool, J48 is an enhanced version of $\mathrm{C} 4.5$ algorithm. The decision tree generated by $\mathrm{C} 4.5$ is used for classification process. [14] [1]

\subsection{K-Nearest Neighbor}

K-Nearest Neighbor is a simple and powerful statistical unsupervised clustering approach. KNN can work with little information or no prior information of data distribution. KNN is also known by various names: Lazy learning, memory based reasoning, example based reasoning, instance based learning, case based reasoning.

\subsection{K-means Clustering}

It is a simplest, quantitative and iterative method used for aggregating enormous sets of data.. An algorithm used to organize the objects based on features into number of clusters. Its main purpose is to define $\mathrm{k}$ centers, one for every 
cluster. These centers should be placed by a deceptive means as different location needs different results. [2]

\subsection{Naïve Bayes}

Naïve Bayes is one of the oldest traditional classification algorithm. Naïve Bayes is extremely attractive because of its simplicity, grace and robustness. It is a statistical and supervised learning method which can resolve difficulty involving both categorical and continuous estimated attributes.

Table 1: Prons and Cons of Classification Techniques

\begin{tabular}{|c|c|c|}
\hline Methods & Advantages & Disadvantages \\
\hline Neural network & $\begin{array}{l}\text { 1. error prone } \\
\text { 2. robust in noise } \\
\text { environment } \\
\text { 3. very efficient }\end{array}$ & $\begin{array}{l}\text { 1.high complexity } \\
\text { model with long } \\
\text { duration of } \\
\text { training } \\
\text { 2. local minima } \\
\text { 3. over fitting }\end{array}$ \\
\hline Decision Tree & $\begin{array}{l}\text { 1.easy to } \\
\text { understand } \\
\text { 2.easily } \\
\text { incorporated into } \\
\text { real time system } \\
\text { 3.produce a set of } \\
\text { rules that are } \\
\text { transparent }\end{array}$ & $\begin{array}{l}\text { 1.Small variation } \\
\text { in data can lead to } \\
\text { different decision } \\
\text { trees. } \\
\text { 2.Does not work } \\
\text { very well on a } \\
\text { small training set }\end{array}$ \\
\hline K-NN & $\begin{array}{l}\text { 1. easy to use and } \\
\text { understand } \\
\text { 2. fast training } \\
\text { required } \\
\text { 3. high } \\
\text { presentation } \\
\text { ability } \\
\text { 4. no optimization }\end{array}$ & $\begin{array}{l}\text { 1. computation } \\
\text { slow } \\
\text { 2. sensitive to } \\
\text { representation } \\
\text { 3.slow testing } \\
\text { 4. huge area for } \\
\text { storage }\end{array}$ \\
\hline $\begin{array}{l}\text { K-means } \\
\text { Clustering }\end{array}$ & $\begin{array}{l}\text { 1. Fast } \\
\text { 2. Easy to } \\
\text { understand } \\
\text { 3. Fairly efficient }\end{array}$ & $\begin{array}{l}\text { 1. Algorithm fails } \\
\text { for non linear } \\
\text { dataset } \\
\text { 2. Unable to } \\
\text { handle turbulent } \\
\text { data and outliers }\end{array}$ \\
\hline Naïve Bayes & $\begin{array}{l}\text { 1. easy to perform } \\
\text { 2.Good outcomes } \\
\text { in most cases } \\
\text { 3. often used as } \\
\text { punching bag for } \\
\text { elegant algorithms }\end{array}$ & Loss of validity \\
\hline
\end{tabular}

\section{DISCUSSION OF PAPERS}

In this literature Survey we present an overview of the current research being carried out using the data mining techniques for the diagnosis and prognosis of various diseases. The following algorithms have been identified: Decision Trees, Artificial neural networks and Naïve Bayes.
Analysis shows that it is very difficult to name a single data mining algorithm as the most suitable for the diagnosis and/or prognosis of diseases. At times some algorithms perform well than others. The Table 2 below shows the survey made in various techniques used in data mining for the medical diagnosis.

Table 2: Literature review

\begin{tabular}{|c|c|c|c|c|}
\hline Author & Year & $\begin{array}{c}\text { Knowledge } \\
\text { Type }\end{array}$ & $\begin{array}{l}\text { Knowledge } \\
\text { resource }\end{array}$ & $\begin{array}{c}\text { DM } \\
\text { techniques/ } \\
\text { applications }\end{array}$ \\
\hline $\begin{array}{l}\text { Jyoti } \\
\text { Soni } \\
\text { et.al } \\
{[13]}\end{array}$ & 2011 & $\begin{array}{c}\text { Heart } \\
\text { Disease } \\
\text { Prediction }\end{array}$ & $\begin{array}{l}\text { Decision tree } \\
\text { outperforms } \\
\text { and } \\
\text { sometimes } \\
\text { Bayesian } \\
\text { classification } \\
\text { 's having } \\
\text { similar } \\
\text { accuracy as } \\
\text { Decision } \\
\text { tree. }\end{array}$ & $\begin{array}{l}\text { Classification: } \\
\text { Clustering } \\
\text { Bayesian } \\
\text { classification, } \\
\text { Neural } \\
\text { Networks } \\
\text { Decision Tree, } \\
\text { KNN }\end{array}$ \\
\hline $\begin{array}{c}\text { Samar } \\
\text { Al- } \\
\text { Qarzaie } \\
\text { et.al [8] }\end{array}$ & 2011 & $\begin{array}{l}\text { Breast } \\
\text { Cancer } \\
\text { Disease }\end{array}$ & $\begin{array}{l}\text { WEKA tool } \\
\text { is used to } \\
\text { give } \\
93.4675 \% \\
\text { accuracy in } \\
\text { testing set } \\
\text { and in the } \\
\text { training set it } \\
\text { yields } 96.8 \% \\
\text { accuracy }\end{array}$ & $\begin{array}{l}\text { Classification: } \\
\text { Decision Tree }\end{array}$ \\
\hline $\begin{array}{c}\text { Arvind } \\
\text { Sharma } \\
\text { et.al } \\
{[11]}\end{array}$ & 2012 & $\begin{array}{l}\text { Blood } \\
\text { Donors }\end{array}$ & $\begin{array}{l}\text { By using } \\
\text { WEKA tool, } \\
\text { J48 decision } \\
\text { tree acquires } \\
89.99 \% \\
\text { accuracy }\end{array}$ & $\begin{array}{l}\text { Classification: } \\
\text { J48 Decision } \\
\text { Tree }\end{array}$ \\
\hline $\begin{array}{c}\text { Shweta } \\
\text { Kharya } \\
{[5]}\end{array}$ & 2012 & $\begin{array}{c}\text { breast cancer } \\
\text { diagnosis } \\
\text { and } \\
\text { prognosis }\end{array}$ & $\begin{array}{l}\text { Decision tree } \\
\text { is a best } \\
\text { predictor } \\
\text { with } 93.62 \% \\
\text { accuracy }\end{array}$ & $\begin{array}{l}\text { Classification: } \\
\text { Neural } \\
\text { Network, } \\
\text { Association, } \\
\text { Naive.Bayes, } \\
\text { C4.5 decision } \\
\text { tree algorithm }\end{array}$ \\
\hline $\begin{array}{c}\text { Dr. } \\
\text { Bushra } \\
\text { M. } \\
\text { Hussan } \\
\text { [3] }\end{array}$ & 2012 & $\begin{array}{c}\text { Prediction of } \\
\text { medical data } \\
\text { by K means } \\
\text { Clustering }\end{array}$ & $\begin{array}{l}\text { On changing } \\
\text { the instances } \\
\text { it shows } 97 \% \\
\text { of accuracy. }\end{array}$ & $\begin{array}{l}\text { Classification: } \\
\text { K-means, } \\
\text { Clustering }\end{array}$ \\
\hline $\begin{array}{c}\text { M. } \\
\text { Durairaj } \\
\text { et.al [2] }\end{array}$ & 2013 & $\begin{array}{c}\text { Applications } \\
\text { in healthcare } \\
\text { sector }\end{array}$ & $\begin{array}{l}\text { WEKA tool } \\
\text { gives } 97.77 \% \\
\text { accuracy for } \\
\text { cancer } \\
\text { prediction } \\
\text { and about } \\
70 \% \\
\text { accuracy for } \\
\text { success rate } \\
\text { of IVF } \\
\text { treatment. }\end{array}$ & $\begin{array}{l}\text { Classification: } \\
\text { Artificial } \\
\text { Neural } \\
\text { Network }\end{array}$ \\
\hline
\end{tabular}




\begin{tabular}{|c|c|c|c|c|}
\hline $\begin{array}{c}\text { Aarti } \\
\text { Sharma } \\
\text { et.al } \\
{[12]}\end{array}$ & 2014 & $\begin{array}{c}\text { Applications } \\
\text { of Data } \\
\text { Mining }\end{array}$ & $\begin{array}{l}\text { Decision tree } \\
\text { shows good } \\
\text { accuracy for } \\
\text { processing } \\
\text { raw data into } \\
\text { information } \\
\text { and find } \\
\text { patterns }\end{array}$ & $\begin{array}{l}\text { Classification: } \\
\text { association, } \\
\text { rule clustering, } \\
\text { prediction and } \\
\text { Evaluation } \\
\text { pattern }\end{array}$ \\
\hline $\begin{array}{l}\text { Mehak } \\
\text { Naib } \\
\text { et.al [7] }\end{array}$ & 2014 & $\begin{array}{l}\text { Predict } \\
\text { Primary } \\
\text { Tumors } \\
\text { using } \\
\text { multiclass } \\
\text { classifier } \\
\text { approach }\end{array}$ & $\begin{array}{l}\text { Multiclass } \\
\text { classifier } \\
\text { gives good } \\
\text { accuracy by } \\
\text { using WEKA } \\
\text { tool than } \\
\text { binary } \\
\text { classifier }\end{array}$ & $\begin{array}{l}\text { Classification: } \\
\text { Random Forest }\end{array}$ \\
\hline
\end{tabular}

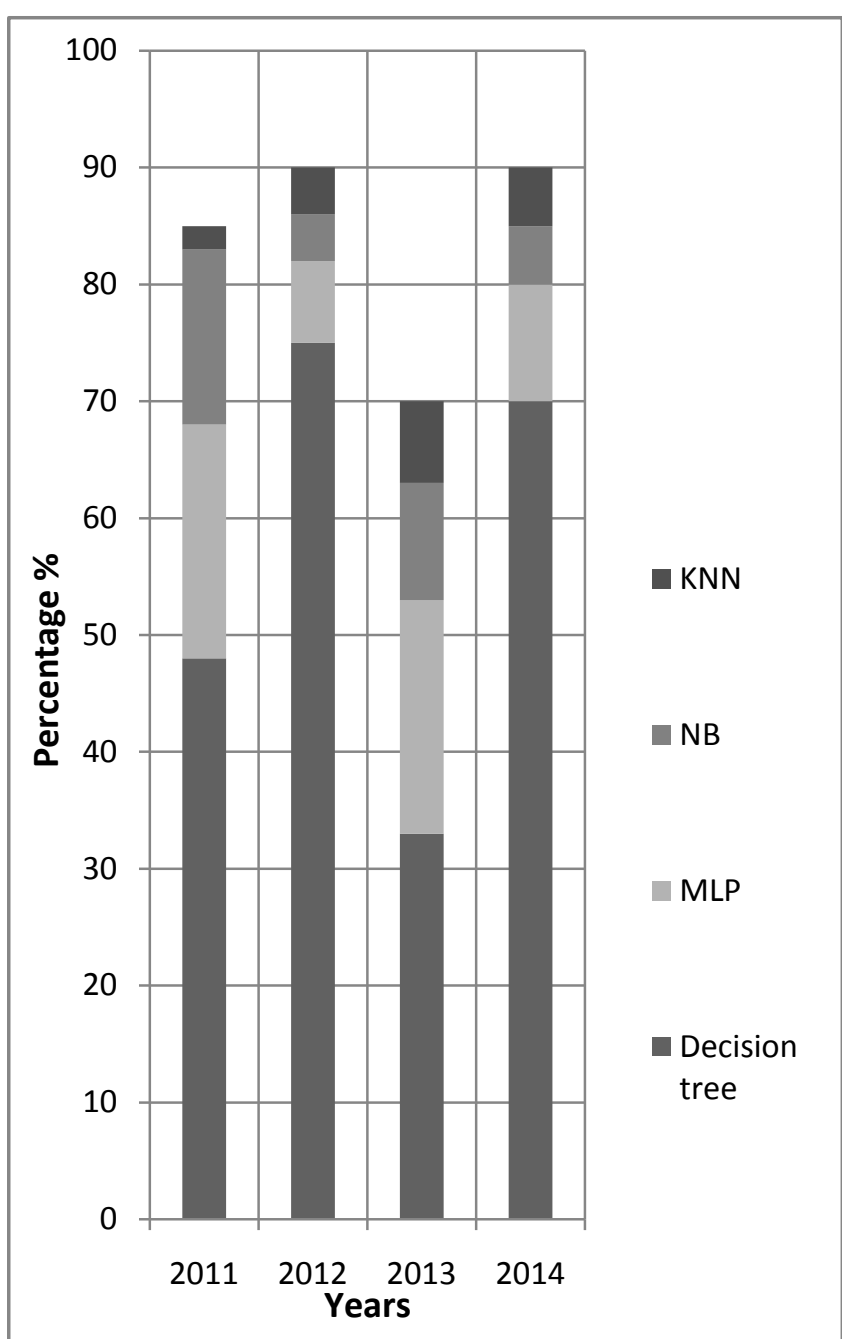

Figure 1: Survey of Algorithms used in Medical datasets

Different algorithms like Decision tree, K- Nearest Neighbor $(\mathrm{KNN})$, Naïve Bayes (NB), Multilayer perceptron (neural network) are used in figure 1 presents that which algorithm is used most in the Literature review in medical field. The outcome reveals that decision tree is the best among other algorithms which shows higher accuracy as compared to other algorithms.

\section{CONCLUSION AND FUTURE SCOPE}

The main purpose of this survey was to discover the most typical data mining algorithms. The ideas of future work include the evaluation of chosen algorithms on the basis of chosen medical dataset. Other algorithms can be applied on built-in dataset and the algorithm which gives best result will be applied on the test dataset. The experiments would be conducted on the selected medical records which design the analysis even more accurate. The good idea is taking also other algorithms to the experiments and compares their performance in medical field. This would evolve a new class and assist in scheming Medical Decision Support Systems by the selection of the most acceptable algorithms. Other methods which are not included in this survey on comparison basis and can discover the best one by assessing the advantages and limitations of the prevailing one.

\section{ACKNOWLEDGEMENT}

This paper using an opportunity to convey the gratitude to parents, experts and friends for their aspiring guidance and helpful encouraging criticism.

\section{REFERENCES}

[1] Chaurasia V. et al. Mining Approaches to Detect Heart Diseases, International Journal of Advanced Computer Science and Information Technology, Vol. 2, No. 4 ISSN: 2296-1739, 56-66.

[2] Durairaj M. et al. 2013. "Data Mining Applications in Healthcare Sector: A Study", International Journal of Scientific and Technology Research, Vol. 2, ISSN 2277-8616.

[3] Hussan D. 2012. "Data Mining based Prediction of Medical data using K-means algorithm”, Basrah Journal of Science(A), Vol. 30(1), 46-56.

[4] Jain N. et al. 2013. "Data Mining Techniques: A Survey Paper", International Journal of Research in Engineering and Technology, Volume: 02, Issue: 11, eISSN: 23191163 | pISSN: 2321-7308.

[5] Kharya S. 2012. "Using Data Mining Techniques for Diagnosis and Prognosis of Cancer Disease", International Journal of Computer Science, Engineering and Information Technology (IJCSEIT), Vol. 2, No. 2.

[6] Mittal P. et al. 2013. "Study and Analysis of Predictive Data Mining Approaches for Clinical Dataset", International Journal of Computer Applications, Volume 63, No. 3 .

[7] Naib M. et al. 2014. "Predicting Primary Tumors using Multiclass Classifier Approach of Data Mining", International Journal of Computer Applications (09758887), Volume 96, No. 8.

[8] Qarzaie S. et al. "Using the Data Mining Techniques for Breast Cancer Early Prediction".

[9] Rani K. 2011. "Analysis of Heart Dksiseases Dataset Using Neural Network Approach”, International Journal of Data Mining and Knowledge Management Process (IJDKP), Vol. 1, No. 5.

[10] Saurkar A. et al. 2014. "A Review Paper on various Data Mining Techniques", International Journal of Advance Research in Computer Science and Software Engineering, Volume 4, Issue 4, ISSN: 2277 128X, pp. 98-101. 
[11] Sharma A. et al. 2012. "Predicting the Number of Blood Donors through their Age and Blood Group by using Data Mining Tool", International Journal of Communications and Computer Technologies, Volume 01, No. 6, ISSN Number: 2278-9723.

[12] Sharma A. et al. 2014. "Applications of Data Mining A Survey Paper", International Journal of Computer Science and Information Technologies, Vol. 5(2), ISSN: 0975-9646, 2023 - 2025.

[13] Soni J. et al. 2011. "Predictive Data Mining Diagnosis: An Overview of Heart Disease Prediction",
International Journal of Computer Applications (0975 8887), Vol. 17, No. 8.

[14] Upadhyay N. et al. 2014. "A Survey on the Classification Techniques in Educational Data Mining", International Journal of Computer Applications Technology and Research, Vol. 3, ISSN 2319-8656, pp. 725-728.

[15] Gennaro Costagliola et.al 2009. "Monitoring Online Tests through Data Visualization", IEEE Transactions on Knowledge \& Data Engineering, Issue No.06 - June, vol.21, pp: 773-784. 